\title{
Effects of Copper (II) Albumin Complex on Thermal Skin Burn
}

\author{
Amany O. Mohamed*, Ahmed Y. Nassar*, Manal A. M. Mandour*, \\ Heba M. Saad Eldien** and Ghada M. E. Mohammed* \\ *Department of Medical Biochemistry and **Department Histology, \\ Faculty of Medicine, Assiut University, Assiut, Egypt
}

\begin{abstract}
Background: Thermal burn results in release of many chemical mediators such as free radicals, biogenic amines and neurotransmitters. The modulations of these mediators can enhance burn wound healing.

Aim of the Work: To evaluate effects of copper (II) albumin complex on thermal wound healing.

Materials and Methods: An animal model of 190 Sprague Dawely rats was established. Ten rats served as a control group and 180 rats were exposed to 10\% total body surface area full thickness thermal burn. The rats were equally divided into three groups and treated topically either with soft paraffin, moist exposed burn ointment (MEBO), or with copper (II) albumin complex. At 4 hours, first day, third day, first week, second week and third week post-injury, plasma was used for determination of malondialdehyde (MDA), total antioxidant capacity (TAC), 5hydroxy tryptamine (5-HT) and gamma amino butyric acid (GABA). Skin tissues were taken for histopathological examination with light microscopy.

Results: Thermal injury resulted in a significant increase of plasma levels of MDA, 5$H T$ and GABA and a significant decrease of TAC. The treated groups with copper (II) albumin complex and MEBO showed a significant decrease of plasma levels of MDA and 5-HT and a significant increase of plasma levels of TAC. Copper (II) albumin complex treatment was associated with a significant increase of plasma levels of GABA at the first and third day post-burn as compared to the other treated groups. Characteristic enhancement of regeneration of epidermis and hair follicles was observed following application of copper (II) albumin complex.

Conclusions: The topical application of copper (II) albumin complex was associated with improved healing signs of full thickness thermal burn due to its antioxidant, antiinflammatory and pain modulating effects.
\end{abstract}

Keywords: thermal burn, copper (II) albumin complex, MEBO 


\section{INTRODUCTION}

Burns are disabling injuries affect all ages and are associated with many problems for patients. Flame and scalds are the most common etiologies ${ }^{(1)}$. Burn produces local proinflammatory mediators which result in edema, wound inflammation and systemic inflammatory syndrome ${ }^{(2)}$. Many studies have shown that oxygen-derived free radicals participate in the pathogenesis of burn tissue damage ${ }^{(3)}$. Release of reactive oxygen species (ROS) in affected tissues results in initiation of lipid peroxidation in burned skin and distant organs $^{(4)}$. ROS, such as superoxide radical, hydroxyl radical and hydrogen peroxide induce tissue damage through peroxidation of lipids, oxidation of protein, and disruption of DNA strands ${ }^{(5)}$. On that base, many antioxidant supplements are used in treatment of burn wound such as $\alpha$-tocopherol ${ }^{(6)}$ and vitamin $\mathrm{C}^{(7)}$.

Following burn injury, a localized and widespread neuroinflammatory process occurs that includes mast cell degranulation, and release of bioamines such as 5Hydroxytryptamine (5-HT), bradykinin, prostaglandins and nerve growth factors ${ }^{(8)}$. 5-HT is an important mediator of the vascular effects of burns in humans resulting in burn edema ${ }^{(9)}$. The increased vascular permeability seen after burn interferes with organ function and healing process.

Uncontrolled burn pain results in release of toxic products and depression of the immunological system ${ }^{(\mathbf{1 0})}$. Reduction of burn pain is a significant sign of healing. GABA plays important role in normal and pathological processes in the skin; it stimulates barrier recovery of the mouse $\operatorname{skin}^{(11)}$. The presynaptic inhibition of GABA neurons by ROS could be an underlying mechanism of neuropathic pain ${ }^{(\mathbf{1 2})}$.

There are many treatment options of burn wounds, including surgical debridement of burned skin and the use of antioxidants ${ }^{(13)}$. MEBO is an ointment consisting of an oily base of sesame oil and bees wax with herbal components comprised of 18 amino acids, 4 fatty acids, 7 polysaccharides, vitamins, and trace elements as copper, plus an active substance consisting of $0.25 \%, \beta$-sitosterol ${ }^{(14)}$. MEBO provides wound healing in a moist environment and assists cellular proliferation through $\beta$ sitosterol action ${ }^{(15)}$. MEBO is widely used as a powerful treating agent of burn wounds, especially partial thickness burn ${ }^{(16)}$

Copper complexes were used as anti inflammatory agents in induced rheumatoid arthritis $^{(17)}$ and non alcoholic fatty degeneration of liver ${ }^{(18)}$. They can act mostly by changing oxidants/ antioxidants properties and scavenging the toxic oxygen species ${ }^{(\mathbf{1 9})}$. Copper nicotinate 
complex had curable effect in full thickness experimental scald burn in rats through anti-inflammatory antioxidant effect ${ }^{(20)}$.

The present work has been designed to investigate the possible effect(s) of the copper (II) albumin complex as an anti-inflammatory and antioxidant agent for promoting experimental burn wound healing

\section{MATERIALS \& METHODS}

All the procedures were performed in accordance with the Assiut University guidelines for care and use of laboratory animals.

\section{Rats and injuries:}

An animal model of 190 SpragueDawely rats of about 100-120 grams body weight was established. Ten rats served as a control group. 180 rats were subjected to brief ether anesthesia and exposed to $10 \%$ total body surface area full thickness thermal burn as described by Santos et al. $^{(21)}$. The rats were equally divided into three groups and treated topically either with soft paraffin, moist exposed burn ointment (MEBO), or with copper (II) albumin complex suspended into soft paraffin. Ten rats from each group were sacrificed at 4 hour, first day, third day, one week, two weeks and three weeks from the beginning of burn induction. Blood and skin tissue samples were collected for biochemical and histological examinations.

\section{Biochemical measurements:}

Malondialdehyde (MDA) was measured by using kit supplied by diagnostics, Egypt; according to the method described by Satoh ${ }^{(22)}$. The total antioxidant capacity (TAC) was measured using kit supplied by diagnostics, Egypt; according to the method described by Koracevic et al., ${ }^{(23)}$. 5-Hydroxy tryptamine (5-HT) was determined by fluorometric method as described by Curzon and Green $^{(24)}$ as modified by Curzon et al., ${ }^{(25)}$. 5-HT forms highly fluorescent complex with O-phthalaldehyde, the addition of $\mathrm{L}$-cysteine to the reaction mixture improves the sensitivity of the method. GABA was determined by fluorometric method ${ }^{(26)}$, where it reacts with ninhydrin and glutamic acid producing fluorescent product.

\section{Histological examinations:}

Skin tissue samples were fixed in $10 \%$ neutral buffered formalin solution, embedded in paraffin wax, cut into $5 \mu \mathrm{m}$-thick sections and stained with hematoxylin and eosin (H\&E) for examination by light microscope.

Statistical analysis: One way analysis of variance (ANOVA) is used to compare between all groups followed by student's unpaired t-test to compare between any two groups

\section{RESULTS}

Four hours post burn injury plasma levels of MDA was significantly increased as compared to 
control group. Paraffin treated group showed an increase of plasma MDA level that continued to the third week as compared to the control group. MEBO and Copper (II) albumin complex treated groups had lower MDA level than paraffin treated group reaching gradually the control level at third week. A summary of these results is shown in table (1). TAC plasma levels were significantly decreased after burn injury as compared with control group. MEBO and copper (II) albumin complex treated group showed significant increase in the plasma TAC to reach to near normal level at the third week of treatment. A summary of these results is shown in table (2). 5-HT plasma levels were increased at the 4 $\mathrm{h}, 24 \mathrm{~h}$ and $72 \mathrm{~h}$ post-burn then decreased reaching control level at the first week in the three treated groups as compared to control group. MEBO and Copper (II) albumin treated groups had lower levels at $24 \mathrm{~h}$ and 72 $\mathrm{h}$ as compared to control group. A summary of these results is shown in table (3). GABA plasma level was significantly increased post-burn injury in the three treated groups until the third week as compared to control group. Copper (II) albumin treatment was associated with significant increase at $24 \mathrm{~h}$ and $72 \mathrm{~h}$ post burn as compared to paraffin. A summary of these results is shown in table (4).

Histopathological examinations of skin sections of burned skin tissues are shown in figure (1). 24 hours after thermal burn, skin sections showed extensive necrosis and degeneration with complete destruction of epidermis, dermis, hair follicles and hypodermis figure (1A). Third week post-burn paraffin treated skin showed (unremarkable) disorganized epidermis and hair follicles (figure 1B). MEBO treated skin showed reepithelization of the epidermis and regenerating hair follicles (figure 1C). Copper (II) albumin treated skin showed regenerated epidermis keratin horns and hair follicle attained normal structure (figure 1D). 
Table (1): plasma MDA vahes (nmol /ml)in control, Paraffim, MEBO and Copper complex treated groups

\begin{tabular}{|c|c|c|c|c|c|c|c|c|c|c|c|c|c|c|c|c|c|c|c|}
\hline \multirow{2}{*}{$\begin{array}{l}\text { paramee } \\
\text { or }\end{array}$} & \multirow[t]{2}{*}{$\begin{array}{l}\text { Control } \\
(\mathrm{n}=10)\end{array}$} & \multicolumn{6}{|c|}{ paraffin treated Group (n= 10) } & \multicolumn{6}{|c|}{ MEBO treated grap $(n=10)$} & \multicolumn{6}{|c|}{ Copper albumin complex treated group $(n=10)$} \\
\hline & & $\mathbf{a t h}$ & $2 \mathrm{th}$ & 72 & $\begin{array}{c}\text { lst } \\
\text { weet }\end{array}$ & $\begin{array}{c}2 \\
\text { week }\end{array}$ & $\begin{array}{c}3 \\
\text { week }\end{array}$ & $\mathbf{4 h}$ & $24 \mathrm{~h}$ & $7 \mathbf{T h}$ & 1stet & $\begin{array}{c}2^{\mathrm{m}} \\
\text { week }\end{array}$ & $\begin{array}{c}3 \\
\text { week }\end{array}$ & $\mathbf{A} \mathbf{h}$ & 24 & $7 \mathbf{A n}$ & 1st & $\begin{array}{c}2^{\mathrm{m}} \\
\text { week }\end{array}$ & $\begin{array}{c}3^{3} \\
\text { week }\end{array}$ \\
\hline$\underset{(\text { inno }}{1 \text { liming }}$ & $\begin{array}{c}1.27 \pm \\
018\end{array}$ & $\begin{array}{c}312 \pm \\
025\end{array}$ & $\begin{array}{c}3.60 \pm \\
0.20\end{array}$ & $\begin{array}{c}5.20 \pm \\
0.30\end{array}$ & $\begin{array}{c}3.30 \pm \\
0.20\end{array}$ & $\begin{array}{c}2.70 \pm \\
0.40\end{array}$ & $\begin{array}{c}2.40 \pm \\
0.20\end{array}$ & $\begin{array}{l}256 \pm \\
0.23\end{array}$ & $\begin{array}{l}3.40 \pm \\
0.20\end{array}$ & $\begin{array}{l}410 \pm \\
060\end{array}$ & $\begin{array}{c}240 \pm \\
020\end{array}$ & $\begin{array}{c}2.03 \pm \\
0.30\end{array}$ & $\begin{array}{c}1.40 \pm \\
010\end{array}$ & $\begin{array}{l}2.90 \pm \\
0.04\end{array}$ & $\begin{array}{c}350 \pm \\
0.30\end{array}$ & $\begin{array}{l}410 \pm \\
010\end{array}$ & $\begin{array}{l}2.20 \pm \\
0.20\end{array}$ & $\begin{array}{c}2.05 \pm \\
0.20\end{array}$ & $\begin{array}{l}1.49 \pm \\
0.02\end{array}$ \\
\hline & & $<0.001$ & $<0.001$ & $\Rightarrow 0001$ & $\Rightarrow 001$ & $<0.001$ & $<0.001$ & $<0.001$ & $<0.001$ & $<0.05$ & $<0.001$ & $<0.001$ & $17:$ & $<0.001$ & $<0.001$ & $\Rightarrow 0.001$ & -0.001 & $\Leftrightarrow 0.001$ & $17:$ \\
\hline & & - & - & - & - & - & - & -0.001 & IT: & $\rightarrow 001$ & $\Rightarrow 0.01$ & $\Rightarrow 001$ & $\Rightarrow 001$ & IT: & $17:$ & -0.001 & -0.001 & $-\infty .001$ & $\rightarrow 001$ \\
\hline
\end{tabular}

Table (2): phasma TAC levels ( $\mu$ ML) in Control, Paraffin, MEBO and Copper (II) albumin complex treated grous

\begin{tabular}{|c|c|c|c|c|c|c|c|c|c|c|c|c|c|c|c|c|c|c|c|}
\hline \multirow{2}{*}{ paramecer } & \multirow[t]{2}{*}{$\begin{array}{l}\text { Control } \\
\text { (n=10) }\end{array}$} & \multicolumn{6}{|c|}{ paraffin treated Group (n= 10) } & \multicolumn{6}{|c|}{ MEBO treated grap ( $n=10$ ) } & \multicolumn{6}{|c|}{ Coppe abumin complex treated grap $(n=10)$} \\
\hline & & Ah & $24 \mathrm{~h}$ & $72 \mathrm{~h}$ & $\begin{array}{l}\text { lat } \\
\text { weet. }\end{array}$ & ${ }_{\text {woet. }}^{2-\infty}$ & $\begin{array}{l}3^{\text {sin }} \\
\text { woet. }\end{array}$ & th & $24 \mathrm{~h}$ & $72 \mathrm{~h}$ & $\begin{array}{l}1 \text { lst } \\
\text { woet. }\end{array}$ & weot. & $\begin{array}{l}3^{\text {nin }} \\
\text { weot. }\end{array}$ & th & $24 \mathrm{~h}$ & $72 \mathrm{~h}$ & $\begin{array}{l}1 \text { st } \\
\text { woet. }\end{array}$ & ${ }_{\text {weet. }}^{2-0}$ & $\begin{array}{l}3^{\text {nat }} \\
\text { weot. }\end{array}$ \\
\hline $\begin{array}{l}\text { TAC } \\
(\mu \mathrm{M} / \mathrm{L})\end{array}$ & $\begin{array}{l}0.61 \pm \\
0.03\end{array}$ & $\begin{array}{c}0.51 \\
\pm \\
\pm 0.04\end{array}$ & $\begin{array}{c}0.42 \div \pm \\
0.03\end{array}$ & $\begin{array}{c}0.33 \div \pm \\
0.04\end{array}$ & $\begin{array}{c}0.45 \pm^{*} \\
0.01\end{array}$ & $\begin{array}{c}0.514 \\
0.04\end{array}$ & $\begin{array}{c}0.56 * \pm \\
0.02\end{array}$ & $\begin{array}{c}0.53 \pm \\
0.04\end{array}$ & $\begin{array}{l}0.44 \pm \\
0.02\end{array}$ & $\begin{array}{c}0.34 \pm \\
0.02\end{array}$ & $\begin{array}{l}0.52 \pm \\
0.03\end{array}$ & $\begin{array}{l}0.54 \pm \\
0.01\end{array}$ & $\begin{array}{l}0.50 \pm \\
0.02\end{array}$ & $\begin{array}{l}0.54 \pm \\
0.04\end{array}$ & $\begin{array}{l}0.44 \pm \\
0.03\end{array}$ & $\begin{array}{c}0.35 \pm \\
0.03\end{array}$ & $\begin{array}{c}0.54 \pm \\
0.01\end{array}$ & $\begin{array}{c}0.56 \pm \\
0.07\end{array}$ & $\begin{array}{c}0.59 \pm \\
0.03\end{array}$ \\
\hline $\mathbf{n}$ & & -0.001 & $\Leftrightarrow .001$ & -0.001 & -0.001 & -0.001 & $\Rightarrow 0.001$ & -0.001 & $\Rightarrow 0.01$ & $\Rightarrow 001$ & -0.001 & -0.001 & IR: & $\rightarrow 001$ & -0.001 & $\Rightarrow 001$ & $\Rightarrow 001$ & -0.05 & IT: \\
\hline $\mathbf{n}$ & & - & - & - & - & - & - & IT: & IT: & IT: & -0.001 & -0.05 & -0.05 & IT: & IT: & IT: & -0.001 & -0.05 & -0.01 \\
\hline
\end{tabular}

P1: versus control group, p2: versusparaffin treated group . WS: non significant. Data are expressed as mean \pm SD 
Table (3): 5-HT plasma levels (ng/ml) in Control, Paraffin, MEBO and Copper (II) albumin complex treated groups

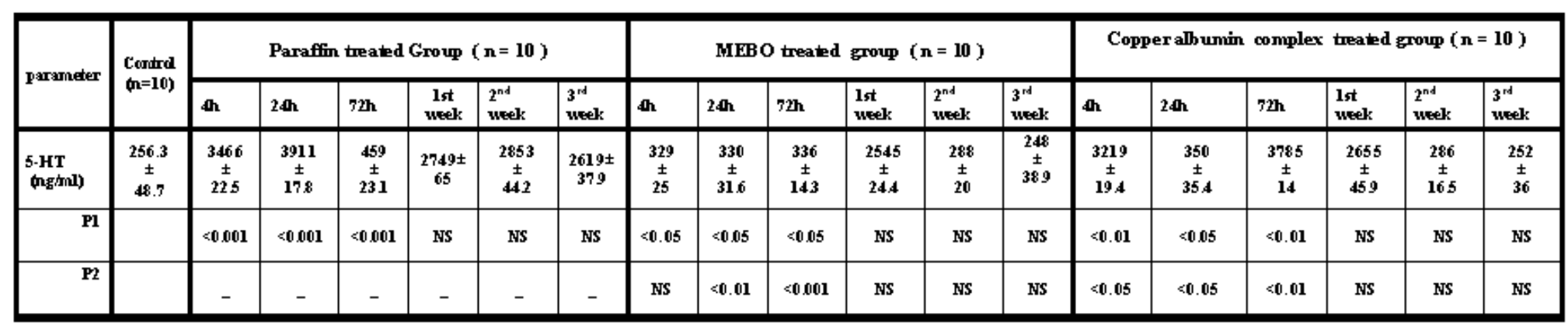

Table (4): GABA plasma levels (g/gl) in Control, Paraffin, MEBO and Copper (II) albumin complex treated groups

\begin{tabular}{|c|c|c|c|c|c|c|c|c|c|c|c|c|c|c|c|c|c|c|c|}
\hline parameter & $\begin{array}{l}\text { Conitrd } \\
(n=10)\end{array}$ & \multicolumn{6}{|c|}{ paraffin treated Group ( $n=60)$} & \multicolumn{6}{|c|}{ MEBO treated group $(n=60)$} & \multicolumn{6}{|c|}{ Copper albumin complex treated group $(n=60)$} \\
\hline & & $<0.001$ & $<0001$ & $<0001$ & $<0.001$ & $<0001$ & $<0001$ & $<0.001$ & $<0001$ & $<0001$ & $<0001$ & $<0.001$ & $<0.001$ & $<0001$ & $<0.001$ & $<0001$ & $<0001$ & $<0001$ & $<0.001$ \\
\hline
\end{tabular}

P1: versus control group, p2: versusparaffin treated group. NS: non significant. Data are expressed as mean土 SD 

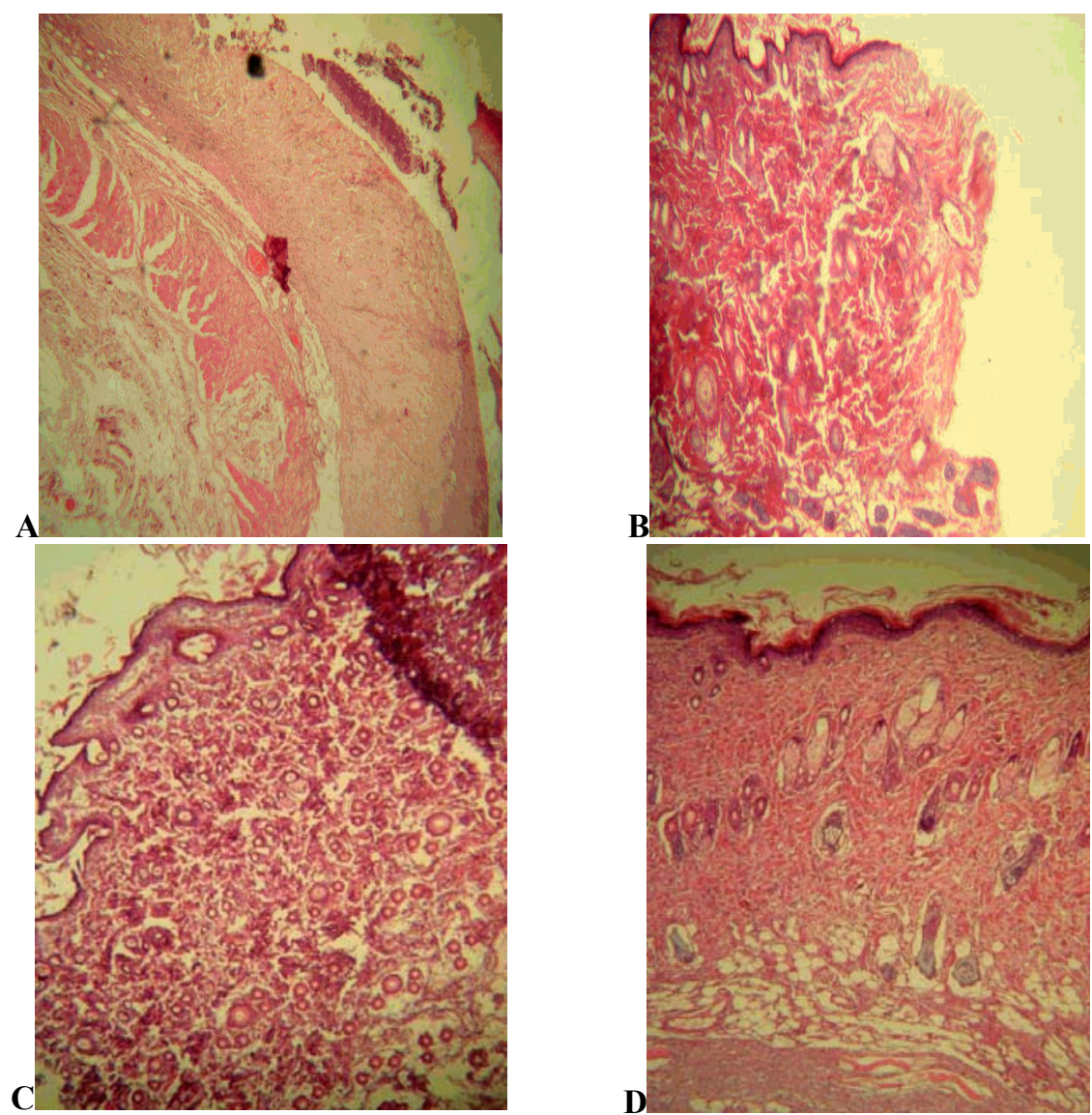

Figure (1): Histopathological changes following thermal burn. (A):24 hour post burn skin tissue shows destruction of epidermis, dermis and hair follicles (H\&E X100). (B): Control treated skin shows disorganized hair follicles and epidermis (H\&E X100). (C): MEBO treated skin shows regenerating epidermis and hair follicles (H\&EX100). (D): Copper (II) albumin complex treated skin shows epidermis with keratin horny layer and regenerating hair follicle (H\&E X100).

\section{DISCUSSION}

During thermal burn reactive oxygen species (ROS) are produced exposing all tissues to oxidative injury ${ }^{(27)}$. In the present study plasma MDA levels were increased significantly following thermal injury as compared to control. This result is consistent with many experimental and clinical studies which had shown that oxygen-derived free radicals rise in the plasma after thermal injury and that rise can be evident one hour postinjury in serum ${ }^{(28,29)}$. High plasma level of MDA in burned rats was 
returned back near the normal level at the third week of treatment with copper (II) albumin complex and MEBO; this finding can be paid to the antioxidant activity of copper (II) albumin complex. Firat et al. (30) suggested that antioxidant drugs may prevent neutrophil-dependent tissue damage and burn-induced oxidative injury.

As regard the mean plasma levels of total antioxidant capacity, the scald injury reduced significantly the total antioxidant capacity as compared with control group. TAC is a sensitive marker of oxidative stress, maintaining low levels throughout the burn with high levels of lipid peroxidation products; this was attributed to oxygen free radicals ${ }^{(31)}$. The total antioxidant plasma levels were gradually increased reaching the control level in copper complex group and MEBO group while not in paraffin treated group at third week of treatment. Copper complexes can increase superoxide dismutase enzyme (SOD) activity, leading to relief of oxidative stress ${ }^{(32,33)}$.

In the current study plasma levels of 5-HT were increased at the first seventy two hour post-burn when compared with control group. Circulating platelets react with exposed collagen, adhere and aggregate and release their content including serotonin ${ }^{(34)}$. These results are in accordance with Samuelsson et al. ${ }^{(35)}$ study. The authors reported that 5-HT was increased in blood and urine during the early phase of the burn. MEBO and copper complex treated groups showed significant decrease in 5-HT plasma levels in the first seventy two hours post-burn as compared with paraffin treated group. This result could be attributed to inhibition of platelets aggregation and cyclooxygenase ${ }^{(36)}$.

Reichl et al., (37) demonstrated that GABAA and GABAB receptors are involved in mediation of mechanical and thermal hyperalgesia after incision wound. In the present study plasma levels of GABA were increased following thermal burn as compared with control group. Copper (II) albumin complex treatment was associated with significant increase of GABA plasma levels at the twenty four hours and at seventy two hours post-burn as compared to paraffin and MEBO treated groups. This action can help in reduction of pain sensation due to decrease in the inflammatory response and decrease of ROS ${ }^{(38)}$. Reactive oxygen species in the spinal dorsal horn could cause neuropathic pain that result from nerve injury or inflammatory insult ${ }^{(39)}$. Inhibition of GABA neurons by ROS in the spinal dorsal horn could be a mechanism explaining neuropathic pain ${ }^{(\mathbf{1 2})}$. Copper complexes have potent analgesic effect in inflammatory model of pain ${ }^{(40)}$.

In our study Copper (II) albumin complex treatment was associated with enhancement of epidermal repithelization and hair follicles regeneration. Shubina and

Shatalin $^{(41)}$ demonstrated that taxifolin and its complexes with iron and copper ions resulted in a more effective skin regeneration and repair of hair follicles due to utilization of toxic metabolites and lipid peroxidation products in chemical burn. 


\section{CONCLUSION}

Copper (II) albumin complex treatment improved healing of full thickness burn. It reduced MDA and increased TAC by antioxidant action. Anti-inflammatory action of that complex resulted in decreased 5-HT. As pain modulating agent it increased GABA level.

\section{REFERENCES}

1. Burd A (2010): Burns: treatment and outcomes. Semin. Plast. Surg., 24(3): 262-280.

2. Evers LH, Bhavsar $D$ and Mailander P (2010): The biology of burn injury. Exp. Derm., 19(9):777-783.

3. Hoşnuter M, Gürel A, Babucçu O, Armutcu F, Kargi E and Işikdemir A (2004): The effect of CAPE on lipid peroxidation and nitric oxide levels in the plasma of rats following thermal injury Burns, 30(2): 121-125.

4. Parihar A, Parihar MS, Milner S, Bhat S. (2008): Oxidative stress and antioxidative mobilization in burn injury. Burns 34(1):6-17.

5. Klaunig JE, Wang $Z$, Pu $X$, Zhou S. (2011): Oxidative stress and oxidative damage in chemical carcinogenesis. Toxi. Appl. Pharm., 254(2):86-99.

6. Traber MG, Leonard SW, Traber DL, Traber LD, Gallagher J, Bobe G, Jeschke MG, Finnerty CC, Herndon D. (2010): $\alpha$-Tocopherol adipose tissue stores are depleted after burn injury in pediatric patients.
Am. J. Clin. Nutr., 92(6): 13781384.

7. Jewo PI, Duru FI, Fadeyibi IO, Saalu LC, Noronha CC. (2012):

The protective role of ascorbic acid in burn-induced testicular damage in rats. Burns 38(1):113119.

8. Mahar PD, Wasiak J, O'Loughlin CJ, Christelis N, Arnold CA, Spinks AB, Danilla S. (2012): Frequency and use of pain assessment tools implemented in randomized controlled trials in the adult burns population: A systematic review. Burns 38(2):147-54.

9. Demling RH (2005): The burn edema process: current concepts. J. Burn Care Rehabil., 26(3):207227.

10. Spanholtz TA, Theodorou $P$, Amini P, Spilker G. (2009): Severe burn injuries: acute and long-term treatment .Dtsch. Arztebl. Int., 106 (38): 607-613.

11. Denda $M$, Inoue $K$, Inomata $S$, Denda S.(2002): Gammaaminobutyric acid (A) receptor agonists accelerate cutaneous barrier recovery and prevent epidermal hyperplasia induced by barrier disruption. J. Invest. Dermatol., 119(5):1041-1047.

12. Yowtak J, Lee KY, Kim HY, Wang J, Kim HK, Chung K, Chung JM. (2011): Reactive oxygen species contribute to neuropathic pain by reducing spinal GABA release. Pain 152(4):844-852.

13. Cetinkale O, Belce A, Konukoglu D, Senyuva C, Gumustas $M K$ and Tas $T$ (1997): Evaluation of lipid 
peroxidation and total antioxidant status in plasma of rats following thermal injury. Burns 23(2):114116.

14. Yong Y. (1999): Analysis of MEBO Cream. Institute of Science and Forensic Medicine, Department of Scientific Services, Health Science Division, Singapore, Report No. 99033191.

15. Subrahmanyam M .(1998): A prospective randomized clinical and histological study of superficial burn wound healing with honey and silver sulfadiazine. Burns, 24(2):157161.

16. Carayanni VJ, Tsati EG, Spyropoulou GC, Antonopoulou FN, Ioannovich JD. (2011): Comparing oil based ointment versus standard practice for the treatment of moderate burns in Greece: a trial based cost effectiveness evaluation. BMC Complement Altern. Med., 11:122.

17. Mandour M, El-Melegy N, Nassar A, Alam N , Mohammed K. (2005): An anti-inflammatory effect of $\mathrm{Cu}$ (I)-Nicotinic acid complex on adjuvant arthritic rat. EJ B M B, 23:1502-1523.

18. Salama RH, Nassar $A Y$, Nafady AA, Mohamed HH. (2007): A novel therapeutic drug copper nicotinic acid complex for nonalcoholic fatty liver. Liver International 27(4): 454-464.

19. El-Saadani MA (2004): A combination therapy with copper nicotinate complex reduces the adverse effects of 5-flourouracil on patients with hepatocellular carcinomas. J. Exp. Oncol., 4(1): 19-24.

20. Nassar MA, Eldien HM, Tawab HS, Saleem TH, Omar HM, Nassar AY, Hussein MR. (2012): Time-dependent morphological and biochemical changes following cutaneous thermal burn-injury and their modulation by copper nicotinate complex: An animal. Ultrastruct. Pathol. J., 36(5):343-355.

21. Santos, F. X., M. Escudero, L. Perez, T. Lozano, J. M. Obispo, C. Hamann, C. Rodriguez (1995): Comparison of the effects of nerve growth factor and superoxide dismutase on vascular extravasation in experimental burns. Burns 21(6): 445-448.

22. Satoh K .1978): Serum lipid peroxide in cerebrovascular disorders determined by a new colorimetric method.. Clin. Chim. Acta 90(1):37.

23. Koracevic D, Koracevic G, Djordjevic V, Andrejevic S and Cosic V(2001): Method for the measurement of antioxidant activity in human fluids. J Clin. Pathol., 54(5):356-361.

24. Curzon $G$ and Green A. (1970): Rapid method for determination of 5- hydroxytryptamine and 5hydroxyindole-acetic acid in small regions of rat brain. Br. J. Pharm., 39(3): 653-55.

25. Curzon G, Kantamaneni BD, Tricklebank MD, (1981): A comparison of an improved Ophthalaldehyde fluorometric method and high pressure liquid chromatography in the determination of brain 5hydroxyindoles of rats treated 
with L-tryptophan and Pchlorophenyl-alanine. $\mathrm{Br}$. J. Pharm., 73(2): 555-561.

26. Pfister $C$ and Wolny $H$ (1980): GABA fluophore formation due to ninhydrin reaction in the octanolic milieu. Spectrofluorometric investigation 1. Acta Histochem., 6(1): 44-49.

27. Park BK, Lee S, Seo JN, Rhee JW, Park JB, Kim YS, Choi IG, Kim YE, Lee Y, Kwon HJ. (2010): Protection of burninduced skin injuries by the flavonoid kaempferol. BMB Rep, 43(1):46-51.

28. Liu DM, Sun BW, Sun ZW, Jin S, Sun Y, Chen X. (2008): Suppression of inflammatory cytokine production and oxidative stress by CO-releasing moleculesliberated $\mathrm{CO}$ in the small intestine of thermally-injured mice. Acta Pharm. Sin., 29(7):838-846.

29. Csontos C, Rezman B, Foldi V, Bogar $L$ and Drenkovics $L$ (2012): Effect of Nacetylcysteine treatment on oxidative stress and inflammation after severe burn. Burns 38(3):428-437.

30. Firat C, Samdanc E, Erbatur S, Aytekin AH, Ak M, Turtay MG and Coban YK (2012): $\beta$ Glucan treatment prevents progressive burn ischemia in the zone of stasis and improves burn healing: An experimental study in rats. Burns March [Epub ahead of print]

31. Jutkiewicz-Sypniewska J, Zembroń-Lacny A, Puchała J, Szyszka $K$ and Gajewski $P$ (2006): Oxidative stress in burnt children. Advances in Medical Science 51:316-320.

32. Duncan $C$ and White $A R$ (2012): Copper complexes as therapeutic agents. Metallomics 4 (2):127-133.

33. Joseph J, Nagashri $K$ and Rani AB (2011): Synthesis, characterization and antimicrobial activities of copper complexes derived from 4-aminoantipyrine derivatives. J.Saud.Chemic.Socie. April 22. [Epub ahead of print]

34. Schrör K and Braun M (1990): Platelets as a source of vasoactive mediators. Stroke 21(12 Suppl.,): 32-35.

35. Samuelsson A, Abdiu A, Wackenfors $A$ and Sjöberg $F$ (2008): Serotonin kinetics in patients with burn injuries: A comparison between the local and systemic responses measured by microdialysis - A pilot study. Burns 34(5): 617-622.

36. Shen ZQ, Chen ZH, Ma GY, Wang DC, Wu WL, Liu WP, Yang YK, Xiong HZ. (1997): Inhibitory effects of copperaspirin complex on platelet aggregation. Zhongguo Yao Li Xue Bao, 18(4):358-362.

37. Reichl S, Augustin M, Zahn PK and Pogatzki-Zahn EM (2012): Peripheral and spinal GABAergic regulation of incisional pain in rats. Pain 153(1):129-141.

38. Janes $K$, NeumannWL and Salvemini D (2012): Antisuperoxide and anti-peroxynitrite strategies in pain suppression. Biochimica et Biophysica Acta 1822(5): 815-821. 
39. Gao X, Kim HK, Chung JM, Chung K. (2007): Reactive oxygen species (ROS) are involved in enhancement of NMDA-receptor phosphorylation in animal models of pain. Pain 131(3):262-271.

40. Gumilar G, Agotegaray M, Bras C, Gandini N, Minetti A and Quinzani $O$ (2012): Antinociceptive activity and toxicity evaluation of $\mathrm{Cu}$ (II)fenoprofenate complexes in mice. Eur. J. Pharmacol., 675(1-3): 3239.

41. Shubina VS and Shatalin IuV. (2012): Effect of the liposomal form of taxifolin complexes with metals of variable valence on skin regeneration after chemical burn. Tsitologia 54(3):251-260. Abstract.

$$
\text { تأثير معقد النحاس الثنائى مع الألبيومين على الحروق المحدثة حر اريا }
$$

الحروق الناتجة عن الحرارة فوق الاحتمال الفسيولوجي تعد من أخطر الاصابات وتؤدى الي تغيرات

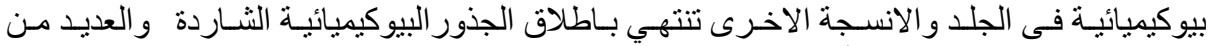

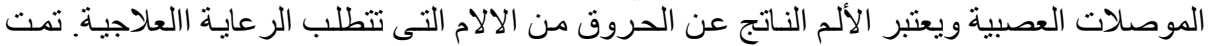

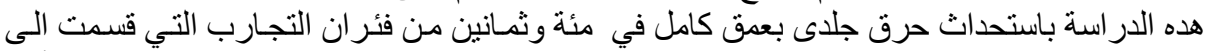

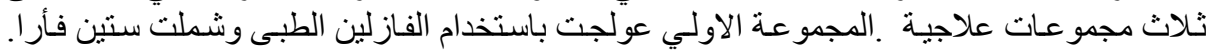

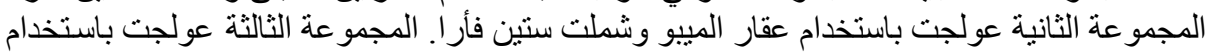

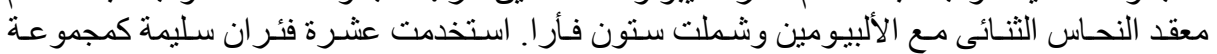

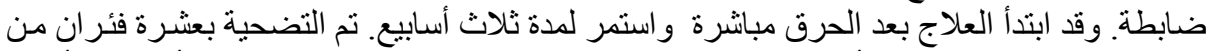

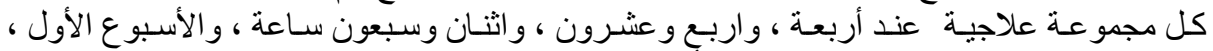

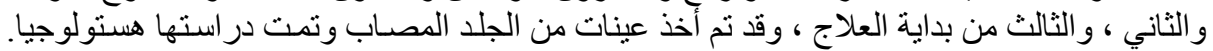

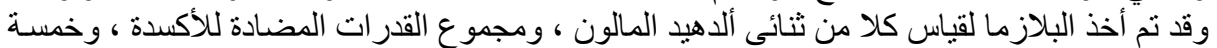

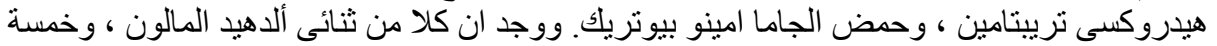

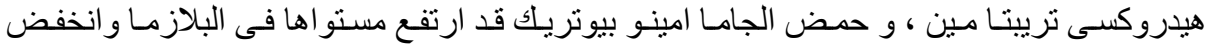

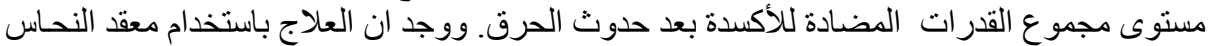

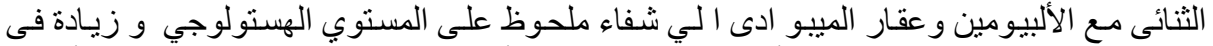

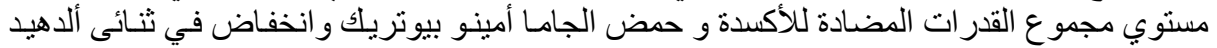

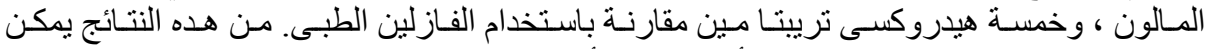

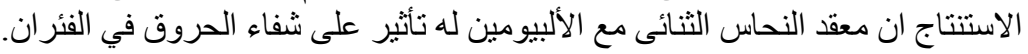

